\title{
Revolution(s): Introduction
}

Christine Lorre-Johnston and Fiona McCann

\section{(2) OpenEdition}

1 Journals

Electronic version

URL: https://journals.openedition.org/ces/572

DOI: $10.4000 /$ ces. 572

ISSN: 2534-6695

\section{Publisher}

SEPC (Société d'études des pays du Commonwealth)

\section{Electronic reference}

Christine Lorre-Johnston and Fiona McCann, "Revolution(s): Introduction", Commonwealth Essays and Studies [Online], 42.1 | 2019, Online since 20 December 2019, connection on 28 September 2021. URL: http://journals.openedition.org/ces/572 ; DOI: https://doi.org/10.4000/ces.572

This text was automatically generated on 28 September 2021

\section{(c) (i) (9)}

Commonwealth Essays and Studies is licensed under a Licence Creative Commons Attribution - Pas d'Utilisation Commerciale - Pas de Modification 4.0 International. 


\title{
Revolution(s): Introduction
}

\author{
Christine Lorre-Johnston and Fiona McCann
}

1 In 2018, the theme for the annual conference of the SAES (Sociéte des Anglicistes de l'Enseignement Supérieur), held at Nanterre University, itself a site of student revolution in the past, was "Revolution(s)," a notion which has particular resonance for the New Literatures panel which provided the genesis of many of the articles included in this issue. Previously colonised countries, as diverse and geographically disparate as India, South Africa, Nigeria, Canada, and Australia (to name but these), have all experienced revolutions in various forms, both during the colonial period and after independence. These revolutions, among which the Canadian rebellions of 1837 and 1838, the 1857-8 uprising in India, the New Zealand wars between 1845 and 1872, the first chimurenga ("uprising" in the Shona language) in Zimbabwe (1894-97), the AngloBoer War (1899-1902), and the Biafran war (1967-70) in some cases paved the way for later twentieth-century rebellions which led to independence and, in some cases, to further revolutions.

2 Hannah Arendt states in her essay On Revolution, that "even if one resists this temptation to equate revolution with the struggle for liberation, instead of identifying revolution with the foundation of freedom, there remains the additional, and in our case more serious, difficulty that there is very little in form or content of the new revolutionary constitutions which was even new, let alone revolutionary" $(1990,142-$ 43). Arendt is referring here to the American and French Revolutions which are often perceived as archetypal, but George Lawson, writing fifty years after Arendt, makes a compelling case against a perception of revolutions as "an attenuated force, a once radical project that has now been domesticated, made safe for a world of communicative capitalism and low-intensity democracy" (2019, x). As he explains it, "political revolutions feature a turnover in state leadership and institutions; social revolutions embrace political, economic, and symbolic fields of action" $(2019,3)$. He goes on to point out that

[i]n their most basic sense, revolutions can be understood as the reorganization of everyday life - they seek permanent shifts rather than temporary changes to the texture of social relations. In this way, revolutions consist of several dimensions simultaneously: a symbolic revolution that seeks to destroy pre-revolutionary 
tropes and reforge new forms of symbolic order; a political revolution that aims to overthrow the old regime and reconstruct systems of governance; and an economic revolution that intends to re-cast relations of production, value, and exchange. (5)

3 However, wary of the pitfalls of homogenising definitions of revolutions, Lawson also cautions that they are "not a single thing, but shapeshifters that modify their form according to the context in which they take place" (249). This is an especially important point in this volume which embraces geographical areas as diverse as South Africa, Nigeria, India, Sri Lanka, and the Caribbean, and which investigates potentially revolutionary aesthetics in various texts. The New Literatures panel in Nanterre invited contributions on the ways in which various revolutions and rebellions have been represented in contemporary postcolonial literature, but especially encouraged papers on the diverse aesthetics deployed from within the vast postcolonial world which have actively destabilised, undermined, and reconfigured genres and canons previously dominated by British literature, and which continue to do so, thereby provoking revolutions within publishing and academic institutions. Many of the articles in this issue analyse literary representations of various uprisings and revolutions and the political agendas at stake, while others focus more on aesthetic innovations and how these contribute to changing the coordinates of local and global postcolonial literatures.

4 In the first article, "The Crisis of Postcolonial Modernity: Queer Adolescence in Shyam Selvadurai's Funny Boy and P. Parivaraj's Shiva and Arun," Sandeep Bakshi explores the interconnection between queer adolescence, revolutions, and postcoloniality. Taking as a point of departure Walter Mignolo's development of the concept of the "coloniality of power," originally coined and conceptualised by Aníbal Quijano, Bakshi investigates two South Asian novels in English published in the 1990s and set in Sri Lanka in the 1970s and India in the 1980s. He analyses the ways in which both authors use queer South Asian adolescence as a means of disrupting Eurocentric conceptions of tradition and modernity. Heteropatriarchy, and its attendant lieutenants, homophobia and heteronormativity are, Bakshi shows, undermined in these novels which foreground queer alliances and queering potential in unexpected sites (the family unit and educational institutions). As Bakshi pinpoints, established ethnic, religious and class hierarchies are also unsettled as the protagonists' homosexual desire and relationships unfold in these narratives, as is the very possibility of defining queerness in the South Asian context which is presented as complicating the colonial version of the binary opposition of tradition and modernity.

5 Inès Bigot's article, "Dance and Dissidence in Wole Soyinka's Plays: From Status Quo to Revolution," investigates the dancing body in the Nigerian writer's dramaturgy and presents it as a means of expressing a subversive message undermining dominant ideological constructs of power and authority. Bigot reads dancing in Soyinka's plays as a potentially revolutionary force, conveying through bodies in movement what cannot quite be articulated through language. Rhythm, intensity, and choreography are, Bigot shows, invested with powerful meaning and constitute an effective means of transcending hierarchies of age, gender, social standing, and political power. Dancing and moving bodies then are invested with the power to re-create personal and communal identity and to become potent weapons against the powers that be.

6 Jayne Chemmachery's article provides an overview of various mutations in the "Mutiny novel" and charts its shift from historical fiction, which borrows variously from the 
codes of Romance or Gothic fiction, adventure novels, melodrama or the chivalric tradition, to historical metafiction. Contextualising the 1857 Mutiny of the Bengal Army as a catalyst for the transfer of power from the East India Company to Britain and for the shift from economic to political dominion, Chemmachery then unpacks the implications of the very term "Mutiny," which positions the event from the point of view of the British, presenting a revolutionary moment of resistance as an act of disobedience. The "Mutiny novel" then emerged as a specifically British genre, replete with hackneyed colonialist stereotypes, whose political function was to justify British presence in India. Chemmachery then identifies two main trends in late twentiethcentury "Mutiny novels," parodic and nostalgic, linking the latter in particular to cultural anxieties about Britain's status in the world. Chemmachery notes that although more contemporary novels in this genre appear to grant increased agency to Indian characters and expose British violence, they nevertheless continue to promote a particular idea of Englishness. Therefore, there has been no real revolution in terms of the genre itself.

7 Shifting the focus from India to the Caribbean, Léo Courbot tackles the works of Fred D'Aguiar through a philosophical lens, looking specifically at some of the poetry of this American writer of Anglo-Guyanese origin. Reading Wilson Harris's concept of "infinite rehearsal" as a revisionary interaction with Nietzsche's concept of perpetual return, and incorporating Jacques Derrida's notion of différance, Courbot analyses d'Aguiar's "imaginative responses to Western-Metaphysical perceptions of time" in two poems published twenty years apart. Revolution in this instance has less to do with rebellion and war, and more to do with literary and philosophical transmutation, and the endless possibilities in literature for shaping the present and reshaping the past. The close personal and literary relationship between D'Aguiar and Harris, transcribed in the poems under scrutiny (and indeed elsewhere in D'Aguiar's œuvre) is, Courbot shows, employed by the younger poet as a means of examining the power of the imagination to provoke temporal slippage.

8 In his analysis of Chigozie Obioma's 2015 novel The Fishermen, Cédric Courtois focuses on the Nigerian author's appropriation of the Bildungsroman genre against the historical backdrop of the 1993 elections and (ultimately) failed transition from military rule to democracy. Courtois suggests that far from being used to promote a conservative agenda, as Bildungsromane have often traditionally done, Obioma's toying with the genre here serves to emphasise a revolutionary politics and aesthetics which exposes the ongoing legacies of colonialism. The Bildungsroman is deployed in The Fisherman, Courtois argues, in an allegorical fashion, and the individual's and the nation's destinies are intricately intertwined. Far from offering closure, as one might expect in a traditional Bildungsroman, Obioma presents the reader with an open-endedness which, although expressing some post-Independence disillusionment, also gestures towards a less chaotic future.

9 Fanny Monnier's article also focuses on Nigerian literature, specifically on Ben Okri's Booker Prize-winning The Famished Road. Set three decades earlier than Obioma's The Fishermen, Okri's novel takes place on the cusp of Nigerian independence and Monnier's analysis discusses revolution as both violent upheaval and the completion of a circular movement, thus investigating both the politics and the stylistics of this text. Monnier shows how Okri presents the revolutionary potential in political terms and undermines it, privileging a circular, spiralling aesthetics which mirrors the permanently unstable 
political situation. Monnier ultimately reads the novel as a project by Okri to provoke a "revolution of the mind," using techniques borrowed from mindfulness and meditation.

10 In her article "A Quiet Revolution: Writing the Indian City on a Minor Mode," Marianne Hillion reads the Indian city against the grain of its common literary representation as monstrous sprawling globalised entity, analysing Siddharth Chowdhury's representation of New Delhi as an ordinary city in a celebration of the vernacular which also includes transcultural elements of hard-boiled and coming-of-age fiction. Hillion shows that this focus on the local and the everyday is no less critical of the negative effects of globalisation and neo-liberal economics and posits this "antispectacular" prism as nothing less than a powerful imaginative revolution. Chowdury's unsentimental, vernacular exploration of the urban space of Delhi, along with the incorporation of Dickensian and popular culture references and a debunking of the epic, Hillion affirms, all contribute to his "quiet revolution" in terms of representing Delhi and enable the author to proffer a fascinating alternative to dominant depictions of the Indian city.

11 Sandra Saayman's article also deals with revolutionary aesthetics and offers a retrospective analysis of South African writer and artist Breyten Breytenbach's work. Saayman argues that Breytenbach's prison writing in particular is arresting less in terms of its content and more in terms of the very texture and grammar of his poetry and prose, and she analyses in particular the overlap of text and image, notably the ways in which the author writes in artistic brush strokes, painting with words. Saayman also emphasises the ways in which Breytenbach engages with the beauty of the ordinary, "the textures and small pleasures of "everyday lovemaking life," and points out that although this writer's work was once considered so revolutionary by the apartheid government that it was banned, its revolutionary essence is more embedded in the plasticity of language and its hermeneutic resistance than in its critical content.

The above articles are all essays whose point of origin can be traced to the fruitful interaction and discussions which took place at Nanterre University in 2018, and yet the two articles included in the Varia section of this issue engage in their own ways with the notion of revolution, whether political or aesthetic. Ellen Turner and Alexandra Poulain turn respectively to Tasmanian historical fiction and South African photography and engage with the politics of representation. Turner looks at two historical romances published by writers Kathleen Graves and Isabelle Dick in the midtwentieth century but which are set in the nineteenth century in Tasmania (Van Diemen's Land) and interrogates the ways in which these novels both recreate a certain past and reveal much about the present in so doing. Through the prism of Georgio Agamben's concept of "bare life," Turner contextualises both the nineteenth-century setting and the mid-twentieth-century context of the authors, particularly the exclusion and genocide of Indigenous people, before examining the representation of Tasmania as a prison camp in the two novels. Turner shows that both novelists engage with the codes of the Gothic romance and set the violence and savagery (as they perceive it) of Van Diemen's Land at a safe distance from their 1940s viewpoint and thereby avoid any engagement with their contemporary era which nevertheless informs their work.

13 Alexandra Poulain's article moves us away from literature and into the realm of photography, and offers an analysis of the politics and aesthetics of South African 
visual activist Zanele Muholi's project "Faces and Phases." Poulain unpacks the ways in which Muholi's portraits of black lesbians and transmen reclaim agency for an invisible community which is often the target of extreme violence by positioning the participants as subjects rather than objects of the gaze. Reading Muholi's project from a decolonial perspective, Poulain considers the political impact of the photographeractivist's reclaiming of space and agency, promoting a "counter-visual distribution of space." Positing the project as a performative intervention in the political sphere, Poulain asserts the affirmative dimension of these photographs which render visible a largely disenfranchised and vulnerable group, and do so in the space of the museum from which the subjects are potentially excluded. Poulain analyses the manner in which the aesthetics of the photographs queer the national narrative and, in the forthright gaze of the participants, reject the asymmetrical one-way gaze so closely associated with colonialist ethnography. Poulain concludes that Muholi's project opens up new perspectives, particularly in its insistence on "inclusion within the visual archive of the emerging nation."

These articles all contribute to extending and rendering more complex familiar debates within postcolonial studies, particularly as regards the politics of literature and the potential for stylistic or aesthetic revolutions to stake new political claims, to render visible vulnerable, marginalised subjects, and to reclaim agency for them.

\section{BIBLIOGRAPHY}

Arendt, Hannah. 1990. On Revolution. 1963. London: Penguin.

Lawson, George. 2019. Anatomies of Revolution. Cambridge: Cambridge University Press.

\section{AUTHORS}

\section{CHRISTINE LORRE-JOHNSTON}

Université Sorbonne Nouvelle - Paris 3, THALIM

Christine Lorre-Johnston is a Senior Lecturer in English at the Sorbonne Nouvelle in Paris. Her research focuses on postcolonial literatures, particularly from Canada and New Zealand, and postcolonial theories. Topics of interest include women's writing, the genre of the short story, and cultural transfers in the context of globalisation. Her most recent publication is a co-edited book on short fiction (Le Format court : récits d'aujourd'hui, Classiques Garnier, 2019). She is editor of Commonwealth Essays and Studies.

\section{FIONA MCCANN}

Université de Lille/CECILLE EA 4074/IUF

Fiona McCann is Professor of Postcolonial Literature at the University of Lille and a Junior Fellow at the Institut Universitaire de France. Her research interests include contemporary Irish and African literatures, border poetics, environmental humanities, and New Materialist and 
decolonial approaches. She has published numerous articles and book chapters, a monograph on violence in Northern Irish fiction, and is currently editing a collection of essays on the carceral network in Ireland (due to be published by Palgrave in 2020). She is President of the SEPC. 